\title{
DNA Labeling at Electron Microscopy
}

\author{
Nicolas Thelen ${ }^{1}$ and Marc Thiry ${ }^{1, *}$ \\ ${ }^{1}$ Giga Neurosciences, Department of Life Sciences, Laboratory of Cell Biology, University of \\ Liège, Quartier Hôpital, 15 Avenue Hippocrate (B36), 4000 Liege, Belgium
}

Email : mthiry@ulg.ac.be

\begin{abstract}
Here, we describe a method for locating DNA on ultrathin sections. This technique is compatible with all usual fixation and embedding procedures and can be combined with cytochemical methods. Ultrathin sections are incubated in a medium containing terminal deoxynucleotidyl transferase (TdT) and various non-isotopic nucleotide analogs. The labeled nucleotides bound to the surface of ultrathin sections are then visualized by an indirect immunogold labeling technique. This high-resolution method provides a powerful tool for pinpointing the precise location of DNA within biological material, even where DNA is present in very low amounts.
\end{abstract}

\section{Keywords}

Terminal deoxynucleotidyl transferase - Immuno-electron microscopy - DNA labelling Immunogold techniques - Immunocytochemistry

\section{Introduction}

Several cytochemical approaches are available for studying DNA distribution at the subcellular level $[1,2]$, including the Feulgen-like reaction with osmium ammine [3-6] and tagging DNA with DNase-gold complexes $[7,8]$. Other strategies involve the use of antibodies directed against DNA [9-12] or against bromodeoxyuridine preincorporated into DNA [13, 14]. Nevertheless, these different techniques are applicable only to biological materials fixed and embedded in a special way, which does not allow excellent morphological distinction between the subcellular components.

Terminal deoxynucleotidyl transferase (TdT) is a DNA polymerase found in pre-lymphocytes and at early stages of lymphoid differentiation [15]. TdT catalyzes a template-independent addition of deoxyribonucleoside triphosphates to the 3'-OH ends of double- or singlestranded DNA during $V(D) J$ recombination [16-19]. While playing a crucial role in the evolution and adaptation of the vertebrate immune system [19-23], this reaction is commonly used in vitro to label the $3^{\prime}$ ends of double- or single-stranded DNA with labeled nucleotides and to add homopolymer tails to DNA fragments [24-26]. By means of tritiated dATP and autoradiography, calf thymus TdT was shown to bind deoxynucleotide monophosphate to the free terminal 3'-OH group of denatured DNA [27], even after fixation and embedding of the biological material in plastic [28]. Adapting this approach for use at the ultrastructural level, Fakan and Modak [29] observed specific labeling, principally of interphase nuclei, nucleolar regions, mitotic chromosomes, and mitochondria. This autoradiographic method is compatible with all fixation and embedding procedures but do not provide high resolution. 
Here we describe a method providing a very useful tool for pinpointing the precise location of DNA in situ within various biological materials at the ultrastructural level [30-32]. The technique includes two successive steps: an enzymatic reaction followed by an immunocytochemical approach; the labeled nucleotides added by TdT on ultrathin sections are then visualized by an indirect immunogold labelling technique involving either an anti-biotin antibody or a monoclonal anti-bromodeoxyuridine antibody and a second, colloidal-goldcoupled antibody [30,33]. This technique is compatible with plenty of fixation and embedding procedures and can be combined with cytochemical methods [31, 32]. Moreover, this technique can be applied to a wide variety of biological materials allowing a sensitive detection of DNA-containing structures, even where these are present in very low amounts [30, 34].

\section{Materials}

Prepare all solutions using boiled bidistilled water and analytical grade reagents. Prepare and store all reagents at room temperature (RT), unless indicated otherwise. Diligently follow all waste disposal regulations when disposing of waste materials.

Any biological material is suitable for the TdT DNA labeling method (see Note 1).

\subsection{Reagents and Tools}

1. Fixative for electron microscopy (see Note 2): $2.5 \%$ (vol/vol) glutaraldehyde in $100 \mathrm{mM}$ sodium cacodylate buffer $(\mathrm{pH} 7.4)$. Store at $4{ }^{\circ} \mathrm{C}$, stable for $1-2$ month.

2. Post-fixation solution: $1 \%$ osmium tetroxyde in $100 \mathrm{mM}$ sodium cacodylate buffer $(\mathrm{pH}$ 7.4). Store at $4{ }^{\circ} \mathrm{C}$, stable for up to 6 months.

3. Phosphate buffered saline (10× PBS): $1.4 \mathrm{M} \mathrm{NaCl}, 60 \mathrm{mM} \mathrm{Na} \mathrm{HPO}_{4}, 40 \mathrm{mM} \mathrm{KH}_{2} \mathrm{PO}_{4}$. Stable at $4{ }^{\circ} \mathrm{C}$ for up to 1 year.

4. Graded series of ethanol solutions.

5. Embedding resin (LX 112 resin, Epon 812 replacement) (see Note 3): Mix in a 25-ml Erlenmeyer flask $5 \mathrm{~g}$ of dodecenyl succinic anhydride (DDSA) with $5 \mathrm{~g}$ of methyl nadic anhydride, $0.3 \mathrm{~g}$ of 2,4,6- dimethylaminomethyl phenol (DMP-30) and $10 \mathrm{~g}$ of LX 112; close the Erlenmeyer flask, stir until the appearance of bubbles and let the mixture rest until the complete disappearance of bubbles. Store at RT, stable for 2-5 days.

6. Graded series of ethanol $100 \%:$ LX 112 solutions.

7. $50 \%$ (wt/vol) ethanolic uranyl acetate : $0.5 \mathrm{~g}$ of uranyl acetate, $12.5 \mathrm{ml}$ of boiled $\mathrm{H}_{2} \mathrm{O}, 12.5$ $\mathrm{ml}$ of ethanol. Store at $4{ }^{\circ} \mathrm{C}$ in a brown glass container or otherwise protected from direct light, stable at $4{ }^{\circ} \mathrm{C}$ for up to 1 year, filter $(0.22 \mu \mathrm{m}$ pore size) before use.

8. Aqueous lead citrate : $4.2 \%$ (wt/vol) sodium citrate, $2.6 \%$ (wt/vol) lead nitrate, add concentrated $\mathrm{NaOH}$ until clearing up of mixture. Stable at $4{ }^{\circ} \mathrm{C}$ for up to 1 year, filter $(0.22$ $\mu \mathrm{m}$ pore size) before use. 
9. Media for Terminal transferase reaction (TdT medium a and $b$ ):

(a) $20 \mu \mathrm{M} 5$ bromo-2-deoxyuridine triphosphate, $100 \mathrm{mM}$ sodium cacodylate $(\mathrm{pH}$

6.5), $2 \mathrm{mM} \mathrm{CoCl}, 10 \mathrm{mM} \beta$-mercaptoethanol, $50 \mu \mathrm{g} / \mathrm{ml}$ bovine serum albumin (BSA), and $125 \mathrm{U} / \mathrm{ml}$ calf thymus TdT.

(b) TdT medium a, supplemented with $4 \mu \mathrm{M}$ each of dCTP, dGTP, and dATP.

10. Saturated solution of sodium metaperiodate.

11. Mouse monoclonal anti-bromodeoxyuridine antibody (Roche).

12. Goat anti-mouse IgG coupled to gold particles $10 \mathrm{~nm}$ in diameter (Amersham Biosciences).

13. Platinum wire (0.1 $\mathrm{mm}$ in diameter).

14. 200 or $300-$ mesh nickel grids.

15. Anticapillary forceps style 7 or style 5.

\section{Methods}

Timing: Preparation for electron microscopy (Subheading 3.1, steps 1-10): 5-6 days;

Terminal transferase reaction and immunogold labelling (Subheading 3.2, steps 1-12): 8-9 h; Staining of sections (Subheading 3.3, steps 1-6): $30 \mathrm{~min}$.

\subsection{Preparation for Electron Microscopy}

1. Fix small fragments of biological material for $60 \mathrm{~min}$ at $4{ }^{\circ} \mathrm{C}$ (see Note 1 ).

2. Eliminate the fixative with a pipette and wash three times with sodium cacodylate buffer (pH 7.4) during 10 min at $4{ }^{\circ} \mathrm{C}$.

3. Postfix the biological samples with post-fixation solution for $60 \mathrm{~min}$ at $4{ }^{\circ} \mathrm{C}$.

4. Eliminate the post-fixative with a pipette and wash three times with distilled water during 10 min at $4{ }^{\circ} \mathrm{C}$.

5. Replace the distilled water by a graded series of ethanol solutions for dehydrating the biological samples: ethanol $70 \%$ (vol/vol), $4{ }^{\circ} \mathrm{C}, 15 \mathrm{~min}$; ethanol $95 \%$ (vol/vol), RT, $5 \mathrm{~min}$; ethanol $100 \%$ (vol/vol), RT, 3× 20 min.

6. Eliminate the solvent with a pipette and impregnate progressively the biological samples at RT in a graded series of alcoholic LX 112 solutions as follows: ethanol $100 \%$ :LX 112, 2:1, 60 min; ethanol $100 \%: L X 112,1: 1,60$ min; ethanol $100 \%: L X 112,1: 2,60$ min; pure LX 112, overnight.

7. Embed the biological samples in fresh LX 112 .

8. Polymerize resin for 3-4 days in an incubator at $42^{\circ} \mathrm{C}$ (see Note 4 ). 
9. Cut ultrathin sections of LX 112-embedded samples on an ultramicrotome with a diamond knife at 60-90 nm.

10. Collect ultrathin sections with a platinum ring ( $4 \mathrm{~mm}$ diameter) formed by a platinum wire and store them on distilled water (see Note 5).

\subsection{Terminal Transferase Reaction and Immunogold Labeling}

1. Incubate ultrathin sections for $30 \mathrm{~min}$ at $37^{\circ} \mathrm{C}$ on the surface of TdT medium a (see Note $6)$.

2. Incubate the sections for $30 \mathrm{~min}$ at $37^{\circ} \mathrm{C}$ on the surface of TdT medium b (see Note 7).

3. Transfer the sections for $60 \mathrm{~min}$ on a saturated solution of sodium metaperiodate at RT (see Note 8).

4. Rinse the sections two times with bidistilled water during 10 min at RT.

5. Incubate the sections for 30 min with PBS containing normal goat serum (NGS) diluted $1 / 30$ and $1 \%$ BSA at RT.

6. Rinse the sections with PBS containing $1 \%$ BSA during 10 min at RT.

7. Incubate the sections for $4 \mathrm{~h}$ at RT in monoclonal anti-BUdR antibody diluted $1 / 50$ in PBS containing $0.2 \%$ BSA and NGS diluted $1 / 50$ (see Note 9).

8. Rinse the sections three times with PBS containing $1 \%$ BSA during 10 min at RT.

9. Incubate the sections for $1 \mathrm{~h}$ at RT in goat anti-mouse IgG coupled to gold particles diluted $1 / 40$ with PBS ( $\mathrm{pH} 8.2$ ) containing $0.2 \%$ BSA.

10. Rinse the sections with PBS containing $1 \%$ BSA during 10 min at RT, then rinse them again two times with bidistilled water during 10 min at RT.

11. Depose ultrathin sections on 200- to 300-mesh nickel grids coated with collodion film (see Note 10).

12. Dry grids on filter paper (see Note 11).

\subsection{Staining of Sections}

1. Transfer grids into a petri dish with reduced $\mathrm{CO}_{2}$ concentration (sodium hydroxide pellets in a petri dish). Incubate for $5 \mathrm{~min}$ at RT in darkness, on drops (20 $\mu \mathrm{l})$ of $50 \%$ ethanolic uranyl acetate (see Note 12 ).

2. Rinse grids in three $25-\mathrm{ml}$ beakers filled with bidistilled water (see Note 13 ).

3. Dry grids on filter paper. 
4. Transfer grids into a petri dish with reduced $\mathrm{CO}_{2}$ concentration (sodium hydroxide pellets in a petri dish) for $5 \mathrm{~min}$ at RT, on drops ( $20 \mu \mathrm{l}$ ) of aqueous lead citrate (see Note 12).

5. Rinse grids in three $25-\mathrm{ml}$ beakers filled with bidistilled water (see Note 13 ).

6. Dry grids on filter paper (see Note 11).

7. Examine ultrathin sections in a transmission electron microscope at 60-80 kV (see Fig. 1).

Fig. 1

Location of DNA in the lizard, Jalapura splendida (a), and in the symbiont-containing trypanosomatid Blastocrithidia culicis (b) using the TdT DNA labeling technique. An acetylation method was applied to increase the contrast of condensed chromatin blocks (c) and between various nucleolar components. D dense fibrillar component, $\mathrm{F}$ flagellum, $\mathrm{Fc}$ fibrillar center, $\mathrm{G}$ granular component, $\mathrm{K}$ kinetoplast, $\mathrm{M}$ mitochondria, $\mathrm{N}$ nucleus. Bar represents $0.5 \mu \mathrm{m}$
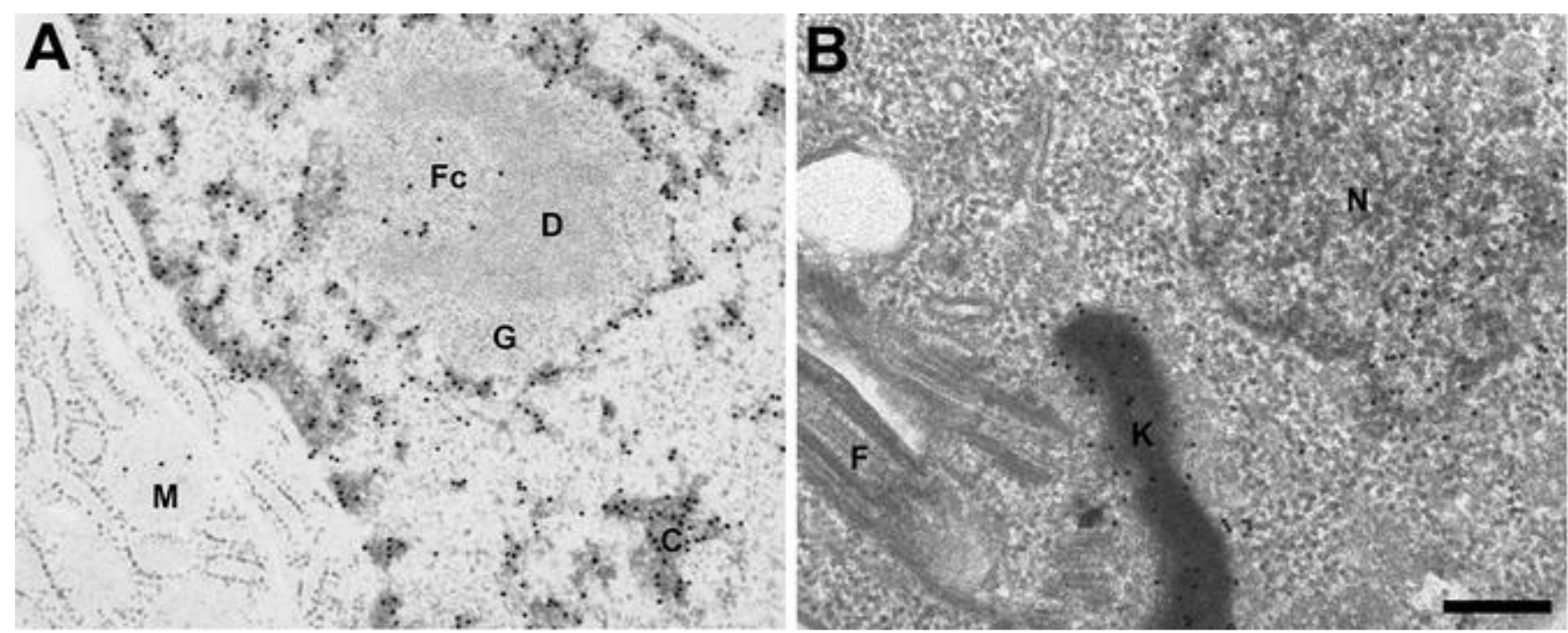

\section{Notes}

1. The technique can be applied to a wide variety of biological materials. See ref. 31,34 for examples of high resolution and sensitive detection include the DNA present in mitochondria, chloroplasts, mycoplasmas, DNA viruses and nucleoli of various animal cell lines or tissues.

2. Other fixatives and buffers can be used. For example: $4 \%$ formaldehyde, $0.2-2.5 \%$ glutaraldehyde, $2.5 \%$ glutaraldehyde/2 \% osmium tetroxide, $5 \%$ acrolein, or $4 \%$ formaldehyde, $0.1 \%$ glutaraldehydein 0.1 M Sorensen's buffer ( $\mathrm{pH} 7.4$ ) (see ref. 30) 3. Other plastic embedding procedure such as Lowicryl K4M (see ref. 35) or LR White using the technique of Newman and Jasani (see ref. 36) can also be used.

4. Polymerized resin can be stored at RT for several months in a closed dish. 
5. Steps $10-20$ are performed on drops of medium placed on parafilm in moist petri dish; a platinum ring is used to move the ultrathin sections on a drop of medium to another. Always keep the same face of the sections in contact with the medium. Do not let the sections dry.

6. First control experiments are carried out: TdT and/or labeled nucleotides are omitted from the TdT medium.

7. This step is indispensable because it has been demonstrated that the anti-BUdR antibody weakly detects BUdR on single-stranded tails of DNA (see ref. 37 ).

8. This step is used to increase the hydrophilicity of LX 112, allowing to obtain more intense labeling.

9. Second control experiment is carried out: the monoclonal anti-BUdR antibody is omitted.

10. The coating of grids with a collodion film is important to avoid the detachment of sections.

11. The grids can be stored at RT for several months on filter paper placed in a closed petri dish.

12. Steps 23 and 26 are performed on drops of medium placed on parafilm in moist petri dish; the face of the grid with ultrathin sections is floated or incubated on the drops of the medium. Before each incubation of grids on drops, the edge of grids and the face of grids devoid of ultrathin sections have to be blotted on filter paper to avoid dipping of grids.

13. The washing procedure is performed in beakers by agitating the grids for $10 \mathrm{~s}$ using anticapillary forceps.

\section{References}

1. Moyne G (1980) Methods in ultrastructural cytochemistry of the cell nucleus. Prog Histochem Cytochem 13:1-72

2. Gautier A (1976) Ultrastructural localization of DNA in ultrathin tissue sections. Int Rev Cytol 44:113-191

3. Cogliati R, Gautier A (1973) Mise en évidence de l'ADN et des polysaccharides à l'aide d'un nouveau réactif "de type Schiff.". C R Acad Sci 276:3041-3044

4. Derenzini M, Viron A, Puvion-Dutilleul F (1982) The Feulgen-like osmium-ammine reaction as a tool to investigate chromatin structure in thin sections. J Ultrastruct Res 80:133-147

5. Olins AL, Moyer BA, Kim SH, Allison DP (1989) Synthesis of a more stable osmium ammine electron-dense DNA stain. J Histochem Cytochem 37:395-398

6. Masiello I, Biggiogera M (2017) Osmium ammine for staining DNA at electron microscopy. In: Pellicciari C, Biggiogera M (eds) Histemistry of single molecules. Humana press, New York 7. Bendayan M (1981) Ultrastructural localization of nuclei acids by the use of enzyme-gold complexes. J Histochem Cytochem 29:531-541 
8. Bendayan M (1982) Ultrastructural localization of nucleic acids by the use of enzyme-gold complexes: influence of fixation and embedding. Biol Cell 43:153

9. Raska I, Armbruster BL, Jira M et al (1984) Ultrastructural localization of DNA in tissue culture cell nuclei by means of enzyme-gold and autoimmune sera-protein A-gold techniques. Biol Cell 48:211-214

10. Hansmann $P$, Falk $H$, Scheer U, Sitte $P(1986)$ Ultrastructural localization of DNA in two cryptomonas species by use of a monoclonal DNA antibody. Eur J Cell Biol 42:152-160

11. Scheer U, Messner K, Hazan R et al (1987) High sensitivity immunolocalization of double and single-stranded DNA by a monoclonal antibody. Eur J Cell Biol 43:358-371

12. Thiry M, Scheer U, Goessens G (1988) Localization of DNA within Ehrlich tumour cell nucleoli by immunoelectron microscopy. Biol Cell 63:27-34

13. Thiry M, Dombrowicz D (1988) Anti-bromodeoxyuridine monoclonal antibody: an alternative tool for the identification of replicated DNA at the electron microscope level. Biol Cell 62:99-102

14. Thiry M (1988) Immunoelectron microscope localization of bromodeoxyuridine incorporated into DNA of Ehrlich tumor cell nucleoli. Exp Cell Res 179:204-213

15. Chang LM, Bollum FJ (1986) Molecular biology of terminal transferase. CRC Crit Rev Biochem 21:27-52

16. Bollum FJFJ (1974) Terminal deoxynucleotidyl transferase enzyme. Elsevier, New York, NY, pp 145-171

17. Baltimore $D(1974)$ Is terminal deoxynucleotidyl transferase a somatic mutagen in lymphocytes? Nature 248:409-411

18. Desiderio SV, Yancopoulos GD, Paskind M et al (1984) Insertion of N regions into heavychain genes is correlated with expression of terminal deoxytransferase in B cells. Nature 311:752-755

19. Motea EA, Berdis AJ (2010) Terminal deoxynucleotidyl transferase: the story of a misguided DNA polymerase. Biochim Biophys Acta 1804:1151-1166. doi:

10.1016/j.bbapap.2009.06.030

20. Bertocci B, De Smet A, Weill J-C, Reynaud C-A (2006) Nonoverlapping functions of DNA polymerases $\mathrm{mu}$, lambda, and terminal deoxynucleotidyltransferase during immunoglobulin $\mathrm{V}(D) \mathrm{J}$ recombination in vivo. Immunity 25:31-41. doi: 10.1016/j.immuni.2006.04.013 21. Kepler TB, Borrero M, Rugerio B et al (1996) Interdependence of $N$ nucleotide addition and recombination site choice in V(D)J rearrangement. J Immunol 157:4451-4457

22. Komori T, Okada A, Stewart V, Alt FW (1993) Lack of N regions in antigen receptor variable region genes of TdT-deficient lymphocytes. Science 261:1171-1175

23. Kunkel TA, Gopinathan KP, Dube DK et al (1986) Rearrangements of DNA mediated by terminal transferase. Proc Natl Acad Sci U S A 83:1867-1871

24. Deng G, Wu R (1983) Terminal transferase: use of the tailing of DNA and for in vitro mutagenesis. Methods Enzymol 100:96-116

25. Michelson AM, Orkin SH (1982) Characterization of the homopolymer tailing reaction catalyzed by terminal deoxynucleotidyl transferase. Implications for the cloning of cDNA. J Biol Chem 257:14773-14782

26. Roychoudhury R, Jay E, Wu R (1976) Terminal labeling and addition of homopolymer tracts to duplex DNA fragments by terminal deoxynucleotidyl transferase. Nucleic Acids Res 3:101-116

27. Modak SP, Bollum FJ (1970) Terminal lens cell differentiation: III. Initiator activity of DNA during nuclear degeneration. Exp Cell Res 62:421-432 
28. Modak SP, Donnelly GM, Karasaki S et al (1973) An enzymatic assay for DNA in epoxytissue-sections by light microscope-autoradiography. Exp Cell Res 76:218-222

29. Fakan S, Modak SP (1973) Localization of DNA in ultrathin tissue sections incubated with terminal deoxynucleotidyl transferase, as visualized by electronmicroscope autoradiography. Exp Cell Res 77:95-104

30. Thiry M (1992) Highly sensitive immunodetection of DNA on sections with exogenous terminal deoxynucleotidyl transferase and non-isotopic nucleotide analogues. J Histochem Cytochem 40:411-419

31. Thiry M, Ploton D, Menager M, Goessens G (1993) Ultrastructural distribution of DNA within the nucleolus of various animal cell lines or tissues revealed by terminal deoxynucleotidyl transferase. Cell Tissue Res 271:33-45. doi: 10.1007/BF00297539

\section{2.}

Lamaye F, Galliot S, Alibardi L et al (2011) Nucleolar structure across evolution: the transition between bi- and tri-compartmentalized nucleoli lies within the class Reptilia. J Struct Biol 174:352-359. doi: 10.1016/j.jsb.2011.02.003

33. Thiry M (1995) Nucleic acid compartmentalization within the cell nucleus by in situ transferase-immunogold techniques. Microsc Res Tech 31:4-21. doi:

10.1002/jemt.1070310103

34. Thiry M (1992) Ultrastructural detection of DNA within the nucleolus by sensitive molecular immunocytochemistry. Exp Cell Res 200:135-144. doi: 10.1016/S0014-

4827(05)80081-3

35. Roth J, Bendayan M, Carlemalm E et al (1981) Enhancement of structural preservation and immunocytochemical staining in low temperature embedded pancreatic tissue. J

Histochem Cytochem 29:663-671. doi: 10.1177/29.5.6166664

36. Newman GR, Jasani B (1984) Post embedding immunoenzyme techniques. In: Polak JM, Varndell IM (eds) Immuno-labelling for electron microscopy. Elsevier, New York, NY, pp 5370

37. Kitazawa S, Takenaka A, Abe $\mathrm{N}$ et al (1989) In situ DNA-RNA hybridization using in vivo bromodeoxyuridine-labeled DNA probe. Histochemistry 92:195-199 